\title{
LAND VALUE CAPTURE MODELING IN COMMERCIAL AND OFFICE AREAS USING A BIG DATA APPROACH
}

\author{
Mohammed Ali Berawi ${ }^{1 *}$, Nyoman Suwartha ${ }^{1}$, Fathiya Salsabila ${ }^{1}$, Gunawan $^{1}$, Perdana Miraj ${ }^{1}$, \\ Roy Woodhead ${ }^{2}$ \\ ${ }^{1}$ Department of Civil Engineering, Faculty of Engineering, Universitas Indonesia, Kampus UI Depok, \\ Depok 16424, Indonesia \\ ${ }^{2}$ Business Operation Systems, Sheffield Business School, Sheffield Hallam University, 38 - 40 Howard \\ Street, Sheffield S1 1WB, United Kingdom
}

(Received: August 2019 / Revised: October 2019 / Accepted: October 2019)

\begin{abstract}
Infrastructure development in Indonesia creates massive impacts on the economy. The Light Rail Transit (LRT) of the greater Jakarta (Jabodebek) project has an estimated cost of more than 29 trillion rupiahs due to land acquisition and route planning. The urban transit development may impact to the price of property including residential, commercial and offices along the route. This research aims to determine variables affecting the price elasticity of property and the correlation to station proximity. Data mining through web scrapping was used to assess the degree of correlation between price elasticity and station location. The result shows that approximately $13 \%$ of commercial property was spread over a distance of $1 \mathrm{~km}$ from the LRT station. The closer a property to transit station, the more likely a price will be twice as cheap compared to those further away. The findings also show variables that highly contribute to property prices, including schools and hospitals, linked to proximity of some transit stations located in city center of Jakarta and building density.
\end{abstract}

Keywords: Commercial property; Data mining; Land value capture; LRT; Transit-oriented development

\section{INTRODUCTION}

Various types of infrastructure are included in the government's long-term projects to create investments and equitable development in Indonesia, increasing demand on the state budget. Infrastructure development recently intensified by the government has been in the rail-based public transportation sector (Berawi et al., 2018a; Rahman et al., 2018). The existing modes of rail transportation in Indonesia are still quite limited, so to expand the network, Mass Rapid Transit (MRT) and Light Rail Transit (LRT) systems have been designed. This paper discusses the LRT project and its construction phases, which have required a total of 29.9 trillion rupiahs originating from the state budget and PT Adhi Karya, an infrastructure development company. Presently, phase A of the construction process is being carried out by Adhi Karya and is expected to be completed in the middle of 2019. In this first phase, the project financing is fully provided by the government. Primary and secondary data are taken to calculate the effects of development on property values around the available stations along the route. This calculation is intended to determine how much the construction of LRT infrastructure influences property price increases in the catchment area, thereby creating valuable insights for the government.

\footnotetext{
*Corresponding author's email: maberawi@eng.ui.ac.id, Tel. +62-21-7270029, Fax. +62-21-7270028 Permalink/DOI: https://dx.doi.org/10.14716/ijtech.v10i6.3640
} 
Value capture is considered in the affected areas by constructing an LRT station as part of the project, and estimating resultant property values.

Land value capture is a public financing technique that captures a fraction of price increases from new public investments and taxes on property or required contributions for repairs. Several cities in the world have used Transit Oriented Development (TOD) to formulate policies and strategies for urban development (Suzuki et al., 2015; Berawi et al., 2019). To carry out value capture, several implementation methods are used, such as property-based developments and others relying on taxes or fees charged on property affected by TOD (Zhang \& Xu, 2017; Cordera et al., 2019). Property values are affected by infrastructure development, especially rail and its characteristics including physical attributes, location, and environment. The impacts from rail infrastructure are diverse and range from insignificant and negative influences to significant and positive attributes (Debrezion et al., 2007; Fahirah 2010). Railway investment is expected to support more compact urban structures and, therefore, serves planning purposes (Fejarang 1993; Mu \& de Jong, 2012).

Physical attributes are among the most influential factors in increasing property values and include factors that directly affect land values. Generally, the physical attributes that affect property prices are divided into four categories: accommodation, materials used, age, and structural conditions (Goldberg, 1981; Zhang \& Xu, 2017). Accommodation further affects the value of land prices due to variations in land uses. Based on various studies conducted, therefore, the number of rooms positively and significantly affects property prices, and prices rise with an increasing number of rooms (Listiyarko \& Ennoch, 2014).

According to Fejarang (1993), property prices are strongly influenced by the characteristics of attractive locations. In other cases, the Central Business District (CBD), which is the center of many urban activities, is also considered to be an attractive quality capable of increasing property prices (Berawi et al., 2018b; Malaitham et al., 2018). Environmental attributes also affect the quality of life of the people utilizing property. However, the quality of life usually depends on the level of comfort of the persons inside and is measured based on land used for commercial or residential purposes with varying results (Medda, 2012).

Several studies have shown that the facilities around properties impact the growth of property values. Zhang and Xu (2017) carried out research in Wuhan, China with data collected in 2015 on two MRT corridor lines, 1,604 houses, 678 commercial units, and 844 office units. By taking such variables, this research considers commercial roadsides, streets, shopping malls, and different areas. The research will also take into account three types of property based on its proximity location. However, the catchment area for commercial property was only cover $300 \mathrm{~m}$ from transit station (Haider \& Miller, 2000).

\section{METHODS}

This research consisted of a case study on LRT Jabodebek in the South Jakarta area. A similar study was previously carried out using data samples from a population, bidding property prices, and data mining approach using the Web Scrapping application. In this research, property prices were obtained from Lamudi.co.id, a large property sales website in Indonesia, and was used to determine other variables that influenced property prices through statistical analytics. After determining which variables significantly affect property, the hedonic price modeling equation was used to predict property prices. Consequently, further calculations had to be carried out to determine how much LRT development influenced property values using the hedonic price modeling method and the property characteristics. For the hedonic price modeling, this research adopts similar variables and method from TOD Wuhan, China with some adjustment taking the context of Jakarta, Indonesia as the case study. 
The sample of property data for this paper came from three sources: property sales websites, statistics Indonesia, and Google Maps. After mining data for commercial and office property, sample properties were identified using Geographic Information Systems (GIS) maps for those located within a distance of $1 \mathrm{~km}$ from stations. This research involved seven LRT stations: Dukuh Atas, Rasuna Said, Karet Kuningan, Kuningan, Cawang, Cikoko Station, and Ciliwung. Identification of properties resulted in more than 900 properties that were then reduced to 114 properties. The other variables that may have affected property prices were collected from statistics Indonesia with school, hospital, CBD, and university locations plotted on the GIS and the distance of a property to transit station calculated. After extraction, the analyzed data were processed using GIS, which helped map properties located $1 \mathrm{~km}$ from LRT stations in South Jakarta.

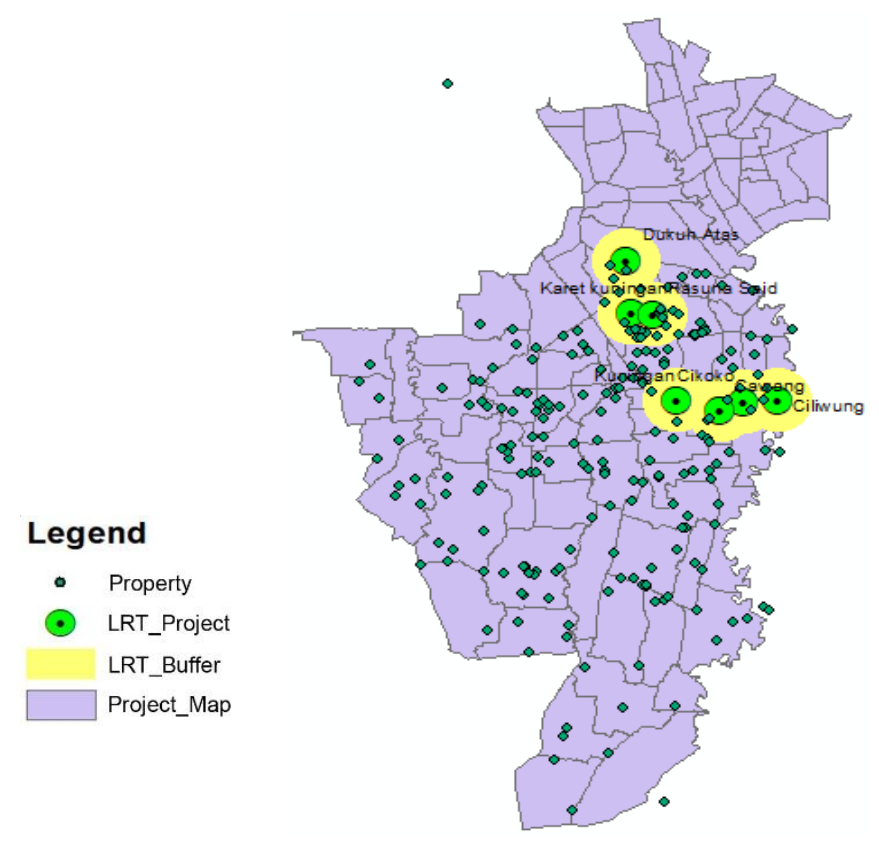

Figure 1 Locations of properties along the LRT line

Figure 1 displays property locations $1 \mathrm{~km}$ from the station based on the requirements of the transit-oriented development concept, which calls for filtering properties in the catchment area based on the distance measured to the station. In this research, SPSS, a statistical analysis tool was used to predict the significance of relationships between dependent and independent variables. In addition, property prices were predicted using the following hedonic modeling equation:

$$
\mathrm{Y}=\alpha+\beta 1 \cdot x 1+\beta 2 \cdot x 2+\beta 3 \cdot x 3+\beta 4 \cdot x 4+\cdots+\mathrm{e}
$$

where $\mathrm{Y}$ is the dependent variable (property prices), $\beta$ is the regression coefficient, $\mathrm{x}$ is the independent variables, and $\mathrm{e}$ is the error value $(5 \%)$. Using this equation, property prices were easily predicted based on variables with significant effects and were included in the equation through a stepwise regression.

\section{RESULTS AND DISCUSSION}

This research investigated the correlation of research variables to property prices. In addition, the correlation coefficients and significance were used to define variables that affected property 
prices. Authors cited above found different variables were affected but still explain the price of property transactions is a function of design, structure, location, accessibility, and environmental variables.

It was found that not all the variables highly correlated to property prices. For instance, in Wuhan, China, there are five variables that highly impacted to the property prices namely the distance from the main road, transport hub, branch hub, impact zone, and CBD. The prices tend to increase the closer to a station showing a positive correlation. This trend reverses the further away it is.

Table 1 Significant variables in Wuhan, China

\begin{tabular}{lcc}
\hline \multicolumn{1}{c}{ Variables } & Correlation & $\begin{array}{c}\text { Non- } \\
\text { Significant } \\
\text { Correlation }\end{array}$ \\
\hline Distance from main road & + & \\
Transport hub & + & \\
Branch hub & + & \\
Impact zone & + & \\
Central Bussiness District & + & \\
Open space & - & \\
Hospital & - & $*$ \\
Floor & - & $*$ \\
Sales in 2015 & + & $*$ \\
School & & \\
Mix with office & & \\
Second hand & & \\
Distance from City centre & & \\
\hline
\end{tabular}

Source: Haider \& Miller, 2000

Two characteristics of the hedonic price modeling is positive impacts on property prices. Furthermore, the study shows results for commercial property indicating that the percentage of commercial properties in one area had significant correlations, while residential areas experience the oppposite effect.

Our analysis found property prices had a wide variance. The price per square meter started at 17 million rupiah, while the highest was 138 million, with an average of 53 million. After analysing results using GIS, SPSS was used to process data and generated the results on the correlations between property prices and characteristics shown in Table 2.

Table 2 Correlations between property prices and characteristics

\begin{tabular}{clcccc}
\hline & & $\begin{array}{c}\text { Ln } \\
\text { Price }\end{array}$ & Ln Distance & Ln Space & Ln Size \\
\hline \multirow{4}{*}{ Ln Price } & $\begin{array}{l}\text { Pearson } \\
\text { Correlation }\end{array}$ & 1 & -0.091 & -0.046 & $.951^{* *}$ \\
& $\begin{array}{l}\text { Sig. (2- } \\
\text { tailed) }\end{array}$ & & 0.380 & 0.659 & 0.000 \\
& $\mathrm{~N}$ & 95 & 95 & 95 & 95 \\
\hline
\end{tabular}


The above table shows that building size was highly correlated to the price elasticity. This can be seen from positive figure of peason correlation near 1 and the significance of a two-tailed test less than 0.05 (i.e. $95 \%$ confidence limit). Furthermore, this research found the test of prices' correlations with the location variable based on proximity to each station. The details of the analysis are shown in Table 3.

Table 3 Correlations between property prices and location

\begin{tabular}{llcccccccc}
\hline & & $\begin{array}{c}\text { Ln } \\
\text { Price }\end{array}$ & $\begin{array}{c}\text { Karet } \\
\text { Kuningan }\end{array}$ & $\begin{array}{c}\text { Dukuh } \\
\text { Atas }\end{array}$ & $\begin{array}{c}\text { Rasuna } \\
\text { Said }\end{array}$ & Cawang & Kuningan & Cikoko & Ciliwung \\
\hline & $\begin{array}{l}\text { Pearson } \\
\text { Correlation }\end{array}$ & 1 & 0.026 & $.212^{*}$ & $-.216^{*}$ & $-.202^{*}$ & 0.135 & -0.008 & 0.113 \\
$\begin{array}{l}\text { Ln } \\
\text { Price }\end{array}$ & $\begin{array}{l}\text { Sig. (2- } \\
\text { tailed) }\end{array}$ & & 0.805 & 0.039 & 0.035 & 0.049 & 0.191 & 0.936 & 0.276 \\
& $\mathrm{~N}$ & 95 & 95 & 95 & 95 & 95 & 95 & 95 & 95 \\
\hline
\end{tabular}

These results show that some transit locations were highly affected the property prices including Dukuh Atas, Rasuna Said, and Cawang stations. Properties prices around Dukun Atas station tend to increase when the transit station operated, shown by positive pearson correlation and less than 0.05 of significance two-tailed. Although the significance of two-tailed tests for both stations (Cawang and Rasuna Said) was less than 0.05, the score of pearson correlation shows a negative correlation. This means, properties around Cawang and Rasuna Said stations tend to became lower despite of transit station operation.

Table 4 Correlations between property prices and environmental factors

\begin{tabular}{llccccc}
\hline & Ln Price & School & Higher education & Hospital & CBD \\
\hline \multirow{2}{*}{ Ln Price } & Pearson Correlation & 1 & $-.212^{*}$ & -0.044 & $-.212^{*}$ & 0.048 \\
& Sig. (2-tailed) & & 0.039 & 0.675 & 0.039 & 0.646 \\
& $\mathrm{~N}$ & 95 & 95 & 95 & 95 & 95 \\
\hline
\end{tabular}

This research included higher education as part of the analysis as higher-education students are a larger population compared to school students, and they will most likely use transit stations for their mobility. The test found that schools and hospitals significantly affect the prices of commercial and office property evidenced by the significance of a two-tailed test yielding a pvalue that is less than 0.05 . This means that with schools and hospitals near the transit station, property prices tend to fall.

\section{CONCLUSION}

Property characteristics have varied impacts on property prices. Based on the benchmarking process taking into account similar TOD project in Wuhan, China, several variables had significant impacts on property prices including the CBD, main road, and schools. However, TOD in Bangkok, Thailand, indicated that distance from public transportation had no significant impacts on property prices and was replaced by job access, density of commercial properties, distance from main roads, distance from the station, time to the CBD, and percentage of vacant building-space. TOD in Rome shows similar result to Wuhan where the location had more 
positive impacts on property prices than access to transportation, while building-age had negative impacts.

This indicates that property prices depend on the location of TOD and variables included on the hedonic price modeling should be adjusted based on the context of case study. This research has identified significant property characteristics based on case studies in Jakarta, Indonesia. Highdensity property and proximity a station of Dukuh Atas were positively correlated to property prices.

\section{ACKNOWLEDGEMENT}

This research was supported by research grants from the Universitas Indonesia and the Ministry of Research, Technology and Higher Education, Republic of Indonesia through Hibah Penelitian Dasar Unggulan Perguruan Tinggi (PDUPT) 2019 (No. NKB-1656/UN2.R3.1/HKP.05.00/2019).

\section{REFERENCES}

Berawi, M.A., Nabila, A., Miraj, P., Rahman, H.A., Berawi, A.RB., 2018a. Analysis of Life Cycle Cost and Public-Private Partnership in the Development of Walini City as Technology Park. International Journal of Technology, Volume 9(7), pp. 1469-1479

Berawi, M.A., Suwartha, N., Kurnia, K., Miraj, P., Berawi, A.RB., 2018b. Forecasting the Land Value around Commuter Rail Stations using Hedonic Price Modeling. International Journal of Technology, Volume 9(7), pp. 1329-1337

Berawi, M.A., Ibrahim, B.E., Miraj, P., 2019. Developing a Conceptual Design of TransitOriented Development to Improve Urban Land Use Planning. Journal of Design and Built Environment, Volume 19(1), pp. 40-48

Cordera, R., Coppola, P., dell'Olio, L., Ibeas, Á., 2019. The Impact of Accessibility by Public Transport on Real Estate Values: A Comparison between the Cities of Rome and Santander. Transportation Research Part A: Policy and Practice, Volume 125, pp. 308-319

Debrezion, G., Pels, E., Rietveld., P., 2007. The Impact of Railway Stations on Residential and Commercial Property Value: A Meta-Analysis. The Journal of Real Estate Finance and Economics, Volume 35(2), pp. 161-180

Fahirah, F., 2010. Identifikasi Faktor yang Mempengaruhi Nilai Jual Lahan dan Bangunan Pada Perumahan Tipe Sederhana (Identification of Factors Affecting the Sale Value of Land and Buildings in Simple Type of Housing). SMARTek, Volume 8(4), pp. 251-269

Fejarang, R.A., 1993. Impact on Property Values: A Study of the Los Angeles Metro Rail. In: Public Transport Planning and Operations. Proceedings of Seminar Held at the European Transport, Highways and Planning $21^{\text {st }}$ Summer Annual Meeting (September 13-17, 1993), UMIST, Volume P370, pp. 27-41

Goldberg, M.A., 1981. Transportation Systems and Urban Forms: Performance Measurement and Data Requirements. In: Proceedings of the International Symposium on Surface Transportation Performance, Volume 259

Haider, M., Miller, E.J., 2000. Effects of Transportation Infrastructure and Location on Residential Real Estate Values: Application of Spatial Autoregressive Techniques. Transportation Research Record, Volume 1722(1), pp. 1-8

Listiyarko, W., Ennoch, S., 2014. Penerapan Model Hedonic dalam Penentuan Nilai Tanah sebagai Referensi dalam Penilaian Barang Milik Negara dan Harga Limit Lelang (Application of the Hedonic Model in Determining Land Value as a Reference in Valuation of State Property and Auction Limit Prices). Avaliable Online at https://bppk.kemenkeu.go.id > publikasi > kajian-akademis, Accessed on August 10, 2019

Malaitham, S., Fukuda, A., Vichiensan, V., Wasuntarasook, V., 2018. Hedonic Pricing Model of Assessed and Market Land Values: A Case Study in Bangkok Metropolitan Area, Thailand. 
Case Studies on Transport Policy. In Press, Corrected Proof. DOI: 10.1016/j.cstp.2018.09.008

Medda, F., 2012. Land Value Capture Finance for Transport Accessibility: A Review. Journal of Transport Geography, Volume 25, pp. 154-161

$\mathrm{Mu}, \mathrm{R}$., de Jong, M., 2012. Establishing the Conditions for Effective Transit-Oriented Development in China: The Case of Dalian. Journal of Transport Geography, Volume 24, pp. 234-249

Rahman, H.Z., Berawi, M.A., Susantono, B., Miraj, P., Petroceany, J.S., Maya, R., 2018. Investigation of an Operation and Maintenance Framework in the railway Industry: A Case Study of the Makassar-Parepare. International Journal of Technology, Volume 9(3), pp. 549-557

Suzuki, H., Murakami, J., Hong, Y.-H., Tamayose, B., 2015. Financing Transit-Oriented Development with Land Values: Adapting Land Value Capture in Developing Countries. World Bank. Washington, United States

Zhang, M., Xu, T., 2017. Uncovering the Potential for Value Capture from Rail Transit Services. Journal of Urban Planning and Development, Volume 143(3), pp. 1-13 